\title{
Chocolate Flavor
}

National Cancer Institute

\section{Source}

National Cancer Institute. Chocolate Flavor. NCI Thesaurus. Code C73376.

A characteristic of a medicinal product, specifying that its most predominant agreeable savor detected by the unified sensation of taste and olfactory receptors resembles chocolate. 